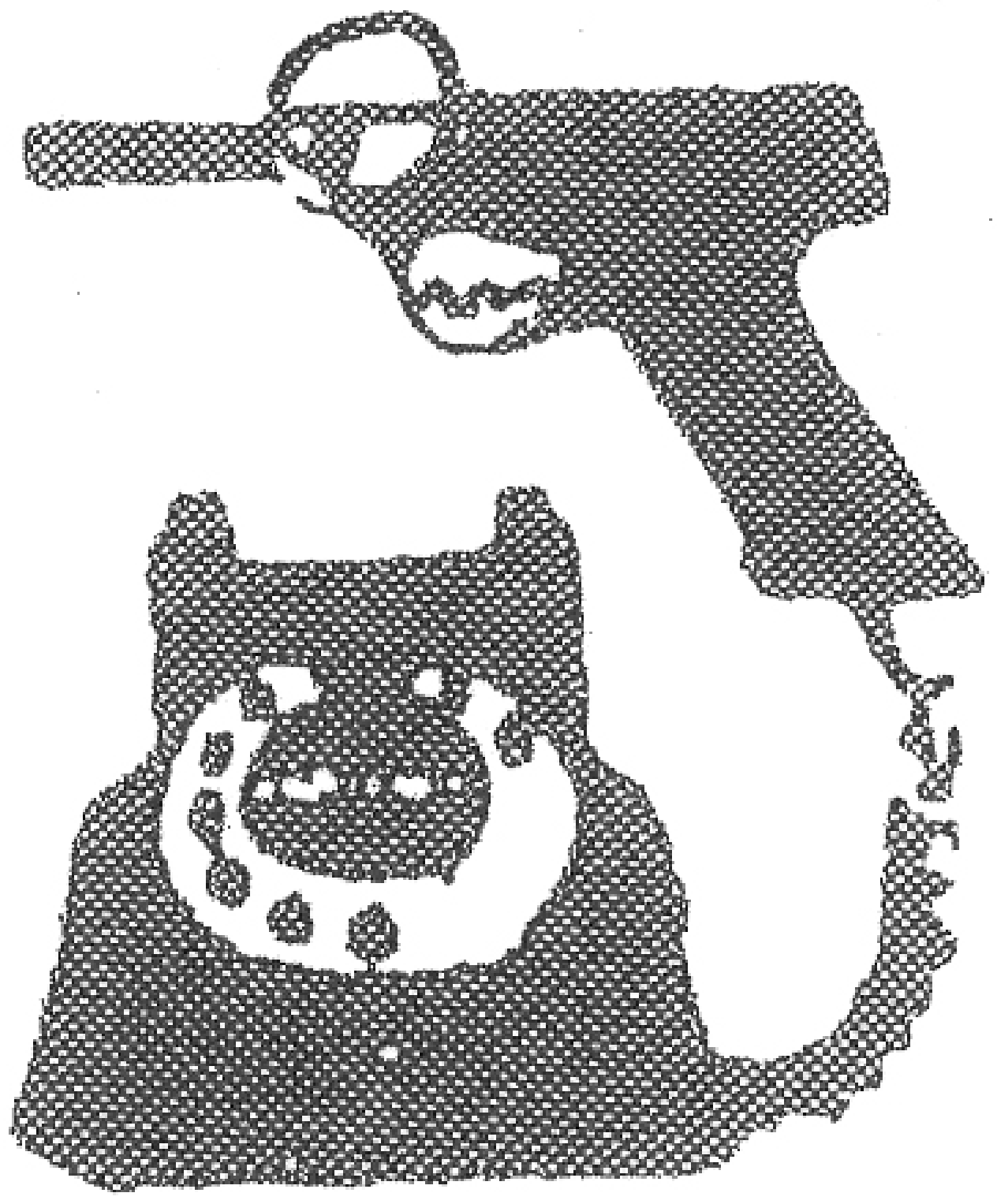




\title{
Alternatieve pers in België na mei '68: Agence de Presse Libération-Belgique
}

\author{
Astrid Waterinckx, licentiate Nieuwste Geschiedenis, UGent, \\ master of Arts in European Studies, K.U.Leuven
}

In het huidige tijdperk van voortschrijdende digitalisering zijn alternatieve nieuwsgaring en berichtgeving een hot item. Het internet bijvoorbeeld, leent zich bij uitstek als medium waar individuen of groepen hun versie van de feiten aan de wereld bekend kunnen maken via blogs, websites, internetradio, ... Maar alternatieve manieren om nieuws te verzamelen en te verspreiden zijn geen nieuw verschijnsel. Ook in de nasleep van mei ' 68 vond een alternatieve persvorm ingang in België. De nieuwe sociale bewegingen die toen actief waren, hadden een forum nodig voor het gedachtegoed dat ze propageerden. Een van de initiatieven binnen dit zeer diverse en diffuse alternatieve perslandschap was het Agence de Presse Libération-Belgique (apl-b of apl). Apl was actief van 1972 tot en met 1993 en omschreef zichzelf als een alternatief persagentschap annex tijdschrift.

\section{Traditionele versus alternatieve pers na mei '68}

De alternatieve media die in het verlengde van het symbolische protestjaar mei ' 68 werden opgericht, vormen op wetenschappelijk vlak een nog zo goed als braakliggend terrein. Het in binnen- en buitenland gevoerde onderzoek is niet alleen zeer beperkt, maar dateert ook bijna exclusief uit de periode waarin deze pers nog actief was of net ter ziele was gegaan. ${ }^{(1)}$ Bovendien zijn het leeuwendeel van de gevoerde studies monografieën, te situeren in de

Logo van Agence de Presse Libération-Belgique (KBR, Brussel) 
sfeer van licentiaatsverhandelingen. Vaak heeft de auteur zelf een meer of minder actieve rol gespeeld in het door hem behandelde persorgaan. ${ }^{(2)}$

De parallelle persinitiatieven die eind jaren 1960, begin jaren 1970 in België en elders ontstonden, worden gekenmerkt door een zeer grote verscheidenheid qua aantal titels, oplage, stijl, informatie, publiek, medewerkers, redactie en distributie, om maar enkele aspecten aan te halen. Tevens is deze pers meestal zeer vluchtig, bewegend en kleinschalig van aard, vele tijdschriften waren een kort leven beschoren en zijn slechts in beperkte oplage verschenen voor een zeer klein publiek. Eén constante brengt deze nieuwe pers evenwel onder dezelfde noemer 'alternatieve pers', namelijk de poging om een antwoord te bieden op een leemte in de traditionele pers.

Met betrekking tot de traditionele pers na mei '68 wordt in de literatuur gewag gemaakt van een 'crisis', voornamelijk dan bij de geschreven pers. ${ }^{(3)}$ Kranten en tijdschriften waren onderhevig aan een sterk concentratieproces. Als gevolg van de stijgende concurrentie van de audiovisuele media streefde de geschreven pers ernaar de eigen positie te versterken. Dit vereiste innovatie en schaalvergroting, wat mogelijk werd door rationalisering en samenwerking. Gevolgen waren onder meer een daling van het aantal titels en het aantal onafhankelijke dagbladondernemingen, afvloeiing van personeel, groeiende investeringen vanuit de reclamesector, omschakeling naar nieuwe technieken zoals offset en fotocompositie, mechanisering, verschuiving van de eigendomsstructuur van familiebedrijven naar financiële holdings, stijgende participatie van buitenlandse groepen, omscholing van de werknemers en introductie van nieuwe niches zoals lokale pers en sensatiepers. De concentratiebeweging van de geschreven pers had met andere woorden zowel een financiële als een technische kant.

Over de repercussies van dit concentratieproces op inhoudelijk vlak, bestaat onenigheid. ${ }^{(4)}$ Inzet van het debat was de bekommernis om pluralisme en diversiteit. België kende traditioneel een gediversifieerd persaanbod, vooral bestaande uit opiniepers. Zowat alle publicaties situeerden zich in het verlengde van een zuilorganisatie, partij of vakbond. Het verdwijnen of samensmelten van persbedrijven zou volgens sommigen tot een verschraling van de diversiteit en pluriformiteit geleid hebben. De steeds sterkere greep van financiële groepen op de geschreven pers zou de pluraliteit in het gedrang gebracht hebben. Anderen beweren dan weer dat kleinere kranten precies door de fusieoperaties konden overleven en dat de geschreven pers in het algemeen door de betere economische situatie een verhoogde kwaliteit kon aanbieden. Zeker is dat de alternatieve pers zelf alvast de 'inhoudelijke' crisis van de traditionele pers aanwees als haar belangrijkste ontstaansreden. De alternatieve pers was van mening dat de traditionele pers enkel geautoriseerde en gefilterde informatie gaf en dat er van echte persvrijheid geen sprake was. De elite had de feitelijke touwtjes in handen en maakte de kleine man monddood. Enkel winstbejag was van tel, niet de informatie op zich. Tegenover deze negatieve vaststelling op het vlak van berichtgeving en vrije meningsuiting, wilde de alternatieve pers op een positieve manier reageren, door eigen niet-traditionele media op te richten die alternatieve 
informatie op een alternatieve manier verzamelden en verspreidden. De alternatieve pers besteedde daarom niet enkel aandacht aan de informatie zelf, maar zette zich ook in om het begrip 'mediaproducent', in de ruimste betekenis van het woord, te herbekijken. Het uiteindelijke doel van deze pers was een andere wereld tot stand brengen; ze was hiermee duidelijk een kind van haar tijd, een product van de 'Stille Revolutie' die eind jaren 1960 de kop opstak. ${ }^{(5)}$

\section{Ontstaansgeschiedenis van apl ${ }^{(6)}$}

Apl-b werd opgericht in 1972 als een van de eerste alternatieve persinitiatieven in Franstalig België. Het was een uitloper van de Leuvense studentencoöperatie L'Oeil $\mathrm{Nu}$, die begin 1972 van start ging met het persagentschap Agence de Presse L'Oeil Nu. Het manifest van apl werd begin september 1972 opgesteld; het eerste tijdschriftnummer verscheen op 18 september 1972.

De directe inspiratie voor apl-b was het Agence de Presse Libération-France, opgericht in juni 1971, in het verlengde van het gezamenlijk protestnummer Spécial Flics dat de maöstische krant La Cause du Peuple en het democratische arbeidersblad J'Accuse hadden uitgebracht. Medestichters van apl-France waren onder meer Maurice Clavel en JeanPaul Sartre. ${ }^{(7)}$ In de schoot van apl-France werd in mei 1973 de - toen zeer linkse - krant Libération opgericht, "le quotidien du quotidien, le journal sans banque, sans publicité", eveneens met Sartre als medestichter. Het persagentschap apl-France bleef los van de krant Libération bestaan, wat niet belette dat 'Libé', zeker in de beginperiode, grotendeels geïnspireerd en gestoffeerd werd door apl-France. In het verlengde van apl-France ontstonden een aantal regionale apl's die actief waren als lokale afdelingen van de hoofdzetel in Parijs. In zekere zin kan apl-b gezien worden als een van die regionale afdelingen.

Apl-b lag op zijn beurt aan de basis van verschillende andere apl's of soortgelijke initiatieven. Naast de hoofdzetel in Brussel, gingen eind 1973, begin 1974 respectievelijk apl-Tournai en apl-Liège van start en even later apl-Charleroi. Ook aan Vlaamse zijde kende apl-b navolging, zo groeide de Leuvense Informatiegroep van de Algemene Studentenraad begin 1975 uit tot het Bevrijdingspersagentschap of bpa.

De voornaamste ontstaansreden van apl-b was dezelfde als die van de andere alternatieve persinitiatieven, namelijk een tekortkoming van de traditionele pers op het vlak van informatie en vrije meningsuiting. ${ }^{(8)}$ Apl vertaalde zijn bekommernissen in een dubbele doelstelling, die gaandeweg werd samengevat in de slagzin 'Lutter sur le front de l'information et donner la parole au peuple.' (9) Enerzijds wou apl, als antwoord op de zogenaamde manipulatie en misleiding in de traditionele media, een vrijplaats zijn voor progressieve journalisten. Ook wou het meer traditionele journalisten mobiliseren en sensibiliseren voor de standpunten van het 'gewone' volk. Anderzijds wou apl een instrument zijn waardoor letterlijk 'une information populaire' of 'volksinformatie' kon 
ontstaan. Via apl moest het nieuws, en dan zeer specifiek de sociale strijd, vanaf de basis worden verslaan. De arbeider in de fabriek, de student aan de universiteit, de man of vrouw in de straat, werkelijk iedereen moest de kans krijgen om rechtstreeks zijn mening kenbaar te maken.

In zekere zin zat de dubbele doelstelling van apl-b ook vervat in het motto 'L'arme de vos informations' dat vanaf nummer 287 (begin 1976) opdook in de apl-tijdschriften. Apl wou een wapen zijn of, zachter uitgedrukt, een hulpmiddel om alternatieve informatie te verzamelen en te verspreiden.

Bij de opstelling van zijn doelstellingen heeft apl-b onmiskenbaar heel wat inspiratie gehaald bij apl-France. Waarschijnlijk is dit niet alleen te verklaren doordat het ene in zekere zin een regionale afdeling was van het andere; beide agentschappen waren sterk maoïstisch geïnspireerd, de kritiek van beide op de traditionele pers en de doelstellingen die ze hiertegenover plaatsten, sluiten alvast mooi aan bij wat in de literatuur omschreven wordt als de marxistische visie op de werking van de pers.

Ondanks de maoïstische sfeer waarin apl-b ontstaan was, stond het op ideologisch vlak geen duidelijke politieke lijn voor en ijverde het zelfs voor politieke onafhankelijkheid. Het wou louter informatie doorgeven over de sociale strijd en deze sociale strijd verbreden. Toch betekent deze onafhankelijke opstelling niet dat politiek niet belangrijk werd geacht, integendeel, apl was sterk politiek geëngageerd, al hing het geen vastomlijnd programma aan. Eerder stond het een vaag afgebakend ideeëngoed voor waarin waarden als vrijheid, gelijkheid en autonomie centraal stonden. Apl was met andere woorden doordrongen van het postmaterialistische, links-libertaire waardesysteem dat zo kenmerkend is voor de periode na mei '68.

\section{Persagentschap annex tijdschrift, of meer? ${ }^{(10)}$}

Apl-b was een persagentschap dat vooral 'anders' wou zijn. Om te beginnen inzake het informatieproces. Het verzond geen berichten via de telex en via de telefoon, enkel bij hoogdringendheid, of om journalisten snel met 'andere' bronnen in contact te brengen. Hét werkinstrument van apl was zijn tijdschrift via hetwelk alle informatie verspreid werd.

Het tijdschrift bereikte exclusief via abonnementen uiteenlopende perskanalen, zowel Le Soir en RTB als Pour, Hebdo en Notre Temps. De geringe afname van het tijdschrift door de pers en het gevoel dat de informatie haar doel niet echt bereikte, deed apl al na enkele maanden besluiten om zijn werkterrein te verruimen. Het tijdschrift werd vormelijk aangepast en voortaan ook rechtstreeks aan de lezers aangeboden. Algauw bestond het bestand van betalende abonnees bijna uitsluitend uit 'gewone mensen', van wie het merendeel in Brussel woonde. De oplage ervan lag nooit erg hoog. Op zijn hoogtepunt 


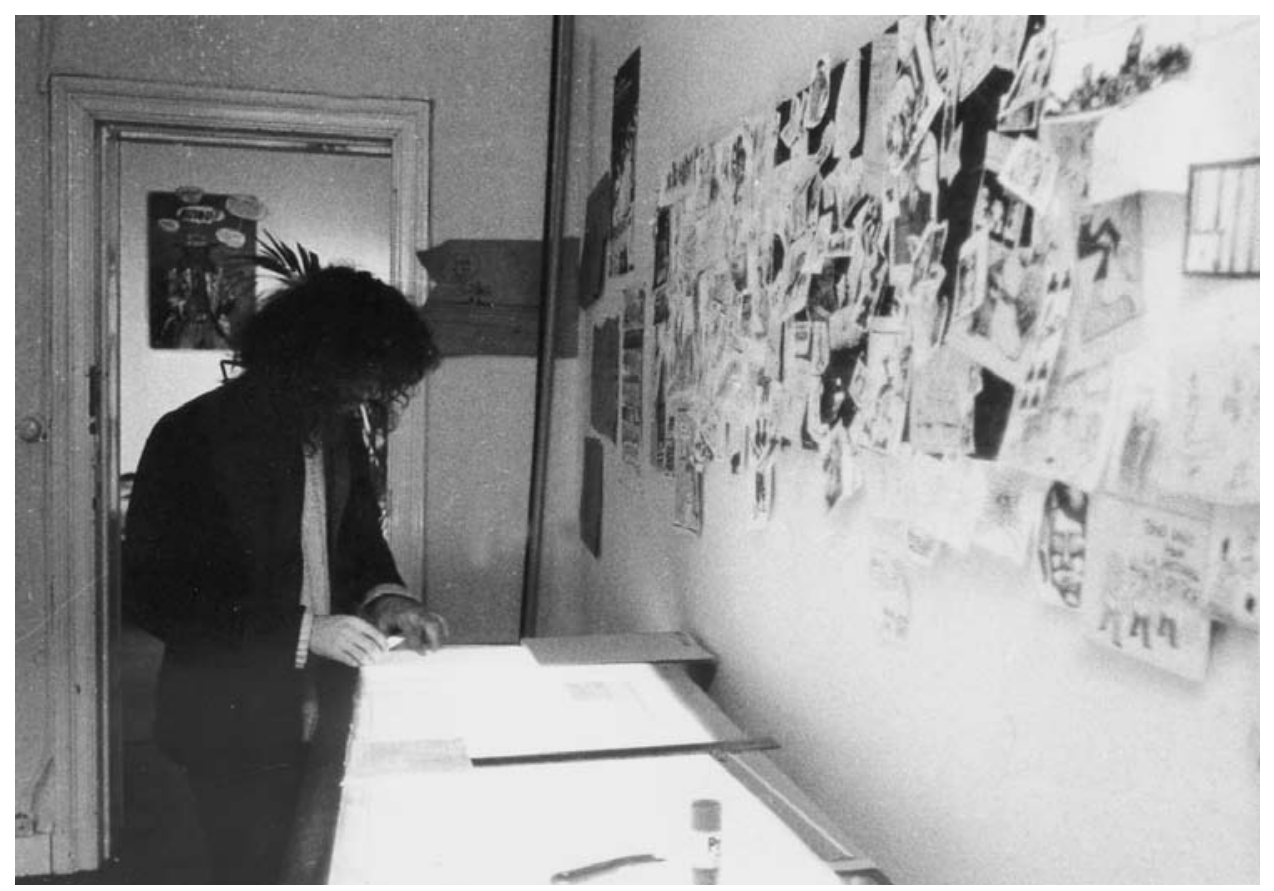

Een apl-medewerker bij de samenstelling van het tijdschrift, jaren 1980

overschreed het aantal abonnees net de kaap van 500. ${ }^{(11)}$ Maar apl streefde geen hoge oplage na, het primaire doel was immers de verspreiding van informatie op gang trekken. Daarom was de vermelding van apl als bron zelfs niet vereist; een vrije reproductie van alle artikels was toegestaan.

Apl-b ontplooide door de jaren heen een hele waaier van nevenactiviteiten die voortdurend groeiden. In het verlengde van het persagentschap had het een tijdje een eigen fotodienst, 'apl-photo', en publiceerde sporadisch dossiers om het publiek te sensibiliseren voor specifieke onderwerpen zoals de staking bij Glaverbel Gilly, de Rote Armee Fraktion, de situatie in Portugal of abortus in België. Daarnaast hield apl een documentatiecentrum open, het organiseerde animatie- en vormingsdagen in het teken van het verstrekken van informatie en de sociale strijd, nam deel aan activiteiten in de alternatieve sector, stelde acties inzake pers en vrije meningsuiting op punt en participeerde in een handvol alternatieve verenigingen zoals EGA (Etat Généraux des mouvements Associatifs/Alternatifs), ALO (Association pour la Libération des Ondes) en RIF (Réseau d'Information Filmée).

Via alle mogelijke kanalen probeerde het agentschap een ander soort informatie aan de man te brengen: "Nous pensons plus que jamais que, en matière d'information alternative, l'écrit doit être complété par d'autres médias.” ${ }^{(12)}$ Het wou verduidelijken dat het informatieproces 
vele facetten kent en het lezerspubliek stimuleren om zelf een stap te zetten in dit proces. Het volstond voor apl duidelijk niet om over de strijd van anderen te berichten; het wou er ook zelf aan deelnemen. Hoe meer zijn nevenactiviteiten groeiden, hoe vager de scheidingslijn ertussen werd. Om die reden wordt apl-b wellicht nog het meest accuraat omschreven als een 'beweging actief op het vlak van alternatieve informatie'.

\section{Informatie over, van en door het volk}

\section{Informatie over het volk ${ }^{(13)}$}

Inhoudelijk stelde apl de 'information populaire' of volksinformatie centraal. Het wou de gebeurtenissen van onderuit weergeven, de stem van 'petites gens' en 'gens de la rue' laten horen. Het wou letterlijk een 'organe de contra-information' worden of een middel dat de traditionele pers zou wakker schudden door informatie te brengen die daarin niet aan bod kwam. In tegenstelling tot de meeste soortgelijke initiatieven, was de focus van apl-b vrij algemeen, een hele reeks thema's passeerde de revue met wel telkens een aantal centrale onderwerpen. Zowat driekwart van de artikels was gewijd aan de sociale strijd, meer specifiek aan de onderwerpen arbeid en nieuwe sociale bewegingen. Bij dit laatste stond het thema derde wereld voorop, gevolgd door de thema's vrede, milieu, seks, vreemdelingen, buurt en onderwijs. Cultuur en jeugd, economie en maatschappij, alternatieve organisaties, verbruikersorganisaties en thema's van de nieuwe sociale bewegingen kwamen slechts beperkt aan bod. Juridische en ideologische onderwerpen en onderwerpen met betrekking tot de media kregen wel veel aandacht.

De toon was progressief-gematigd en met de jaren zwakte de relatief revolutionaire toon verder af. Min of meer parallel hiermee ontwikkelde zich ook de aard van de thema's die aan bod kwamen in het tijdschrift: ideologische onderwerpen, milieu en vreemdelingen kregen een groeiende aandacht, thema's als derde wereld, vrede en arbeid raakten op de achtergrond. Een verklaring hiervoor lijkt van tweeërlei aard. In eerste instantie had het ruimere maatschappelijke gebeuren onmiskenbaar een invloed op de belichte thema's, de toename van ideologische stukken hing bijvoorbeeld samen met de opkomst van extreem rechts, terwijl de mindere belangstelling voor het thema arbeid verklaard kan worden door het geluwde protest van de arbeiders. In tweede instantie was de interne werking van apl van invloed. Bepaalde medewerkers onderhielden sterke banden met specifieke organisaties in de sociale strijd en zaten dus in een bevoorrechte positie om informatie hieromtrent te vergaren en door te geven. Zo was de grote aandacht voor de derde wereld deels te verklaren doordat medewerker Michel Veys naast verantwoordelijk uitgever van apl, ook lid was van het Comité Zaire. 


\section{Informatie van het volk}

Om de informatie te verzamelen, deed apl een beroep op het volk, het vond dat informatie geen zaak was van professionelen - in casu journalisten - maar daarentegen door iedereen ter harte moest worden genomen; vandaar zijn stelling: "Vous n' êtes pas des journalistes? Nous non plus!” (14)

Aanvankelijk ging apl zelf actief op zoek naar informatie. De medewerkers woonden persconferenties bij, namen de traditionele en alternatieve pers door, vroegen per post allerhande brochures, ledenblaadjes, artikels en inlichtingen, trokken naar de plaats van het gebeuren en hadden enkel oog voor wat zich afspeelde aan de basis. Geleidelijk gaf het prioriteit aan de opbouw van een correspondentennetwerk waarbij de artikels, als een 'réflexe apl', werden opgesteld en doorgestuurd door de betrokkenen. Iedere lezer werd beschouwd als een potentiële correspondent of 'abonné-correspondant': "Renforcer l'apl, c'est faire en sorte que chacun se considère comme un correspondant et nous envoie le compte-rendu de ce qui se passe dans son milieu et sa région.” ${ }^{15)}$ Hoewel het op punt stellen van het correspondentennetwerk niet van een leien dakje liep, ontstond geleidelijk een belangrijke groep mensen en organisaties die per post of per telefoon artikels of berichten doorgaven.

\section{Informatie door het volk}

Het verzamelen van informatie, alsook de redactie, productie en distributie van het apltijdschrift, waren taken die door een zeer wisselende ploeg van losse medewerkers werden uitgevoerd. In principe kon eender wie meewerken, maar het tijdschrift werd de facto draaiende gehouden door steeds dezelfde ploeg vaste medewerkers, tijdelijk aangevuld met extra helpers. Het aantal kernmedewerkers varieerde van drie à vier personen in de beginjaren (met als stuwende krachten Maurice Beerblock en Philippe Gautier), over acht à twaalf op het hoogtepunt (o.m. Pascal Delaunois en zijn partner Monique Quintart) en een vijftal of nog minder in de eindfase (Michel Veys). Sporadisch liepen ook enkele studenten er stage en rond 1980 werden kortstondig een aantal btk'ers ingeschakeld. ${ }^{(16)}$ Voorts speelde het principe 'ons kent ons' en 'ons helpt ons' een belangrijke rol; een schot tussen apl en andere verenigingen in de sociale strijd was er niet. Het kwam voor dat wie toevallig langskwam bij apl, een handje toestak. Door deze open, ongedwongen en familiale sfeer, was apl in zekere zin ook een ontmoetingscentrum.

De ploeg medewerkers die het persagentschap annex tijdschrift vorm gaf, was niet alleen erg wisselend, maar ook zeer divers, de leeftijd schommelde tussen 18 en 50 jaar. Vooreerst hadden slechts enkelen een journalistieke opleiding genoten en niemand van hen was ooit op professionele wijze met journalistiek bezig geweest. Een specifieke vooropleiding was ook niet echt vereist; een vorming genoot men in feite bij apl zelf, naar het motto 'Al doende leert men'. Een aantal medewerkers was nog student, de meesten waren actief op de arbeidsmarkt. Velen waren ook actief in verenigingen, in een nieuwe sociale beweging zoals het Collectif Femmes Battues, het Collectif pour la Liberté d'Expression, de Cyclistes quotidiens follement dynamiques, het Comité Zaire, het Amis de la Terre en 
het Front Antifasciste, of in een politieke groepering zoals La Parole au Peuple, Alternative Libertaire en Ligue révolutionnaire des travailleurs. Wat deze medewerkers samenbracht, was hun inzet voor hetzelfde doel: alternatieve informatie brengen. Hiervoor offerden ze heel wat vrije tijd op, het 'bénévolat absolu' was immers een werkprincipe dat apl hoog in het vaandel droeg.

Qua werking stond de 'autogestion' voorop, concreet hield dit in dat alle medewerkers moesten meehelpen met het vervullen van alle taken, zowel materieel als intellectueel. Alle beslissingen moesten daarenboven gezamenlijk genomen worden, iedereen werd verantwoordelijk geacht voor het reilen en zeilen in het persagentschap, hiërarchie en specialisatie werden afgewezen. Niemand had een afgelijnde functie, iedereen was elkaars gelijke en er werd nauwlettend op toegekeken dat niet één persoon meer macht kon verwerven. Het ideaal van een collectief in eigen beheer werd in de praktijk omgezet door een werkrotatie, iedereen moest beurtelings een artikel schrijven, materiaal aankopen, ter plaatse informatie verzamelen, adressen schrijven of stencileren. Door het hele informatieproces voor iedereen toegankelijk te maken en zelfs uit handen te geven, wou apl iedereen het gevoel geven meester te zijn en te blijven over zijn informatie.

Hoewel apl zijn uiterste best deed om dit principe niet te laten uithollen, schortte er af en toe wel iets aan. De droom om ooit 'le seul bulletin qui est fait par ses lecteurs' te worden, werd nooit bewaarheid. De lezers kwamen niet opdagen om de materiële en intellectuele taken op zich te nemen. Gebrek aan hulp werkte niet alleen specialisatie in de hand, in combinatie met het vrijwilligerswerk leidde dit ertoe dat de taken wel eens boven het hoofd van de vaste kern van apl groeiden.

\section{Informatie in woord en beeld ${ }^{(17)}$}

Een groot deel van de redactietaken omvatte slechts het overnemen van toegestuurde berichten en communiqués, ze werden niet op juistheid gecontroleerd. De overige artikels werden opgesteld door de kernleden. De redactie ervan gebeurde in principe collectief; de facto bestond er een zekere specialisatie volgens onderwerp. De artikels werden niet ondertekend, vermits iedereen in gelijke mate verantwoordelijk werd geacht voor de inhoud. Bij de berichten en communiqués daarentegen vermeldde apl zo exact mogelijk de naam van de persoon of organisatie die de informatie had doorgegeven, want het was er ten zeerste voor beducht de woorden van anderen af te drukken en zich de informatie van anderen toe te eigenen. Deze naamsvermelding had dan ook tot doel aan te tonen dat de informatie niet kwam van een specialist, maar van gewone mensen. De artikels kregen een titel en een opgave van plaats, bron, datum en onderwerp. Vervolgens werden ze onderverdeeld in een aantal rubrieken, waarbij allesbehalve consequent te werk werd gegaan. Het aantal, net als de aard, zelfs de plaats van de rubrieken, veranderde doorheen de tijd zeer sterk en zelfs van nummer tot nummer. De enige vaste ijkpunten in het 
tijdschrift waren de rubrieken 'national' en 'international'. In de rubriek 'communiqué' werden - niet altijd even systematisch - de toegestuurde persberichten ondergebracht. In de rubriek 'agenda' werden alle activiteiten aangekondigd die zich situeerden in de alternatieve sfeer (zoals vergaderingen, spektakels of manifestaties georganiseerd door jeugdhuizen, foyers culturels, alternatieve ontmoetingsplaatsen of domeinspecifieke organisaties). In de rubriek 'animation' ('culture' klonk te bourgeois) konden verenigingen verslag uitbrengen over het verloop van hun activiteiten, over hun problemen, strijd en acties. Wanneer op het laatste nippertje interessante berichten binnenliepen bij de redactie, werd een rubriek 'dernière minute' toegevoegd. Overige rubrieken waren 'revue des revues' met een overzicht van de traditionele en de alternatieve pers; 'petite annonce gratuite', 'mot croisé mensuel', 'alternative' waarin onder meer alternatieve vakantietips werden gegeven; 'la grande presse vous a dit' waarin de zogenaamde censuur en leugens van de traditionele pers uit de doeken gedaan werden en 'les aventures d'Arthur et Zoé', een satirische rubriek over dagdagelijkse gebeurtenissen. Sporadisch gaf apl ook 'dossiers' uit, al dan niet in een apart tijdschrift. Buitenbeentje tot slot was de rubriek 'édito'. De editorialen waren geen opiniestukken, maar korte artikels waarin uitleg werd gegeven over hoe het er bij apl aan toeging en allerhande oproepen naar de lezer toe werden gedaan. Ook feestelijk nieuws vond daar een plaatsje.

Qua formule opteerde apl-b voor een zeer soepele vorm: tussen 5 en 45 pagina's per nummer, tussen 1 en 55 artikels per nummer, dat driewekelijks, tweewekelijks, wekelijks, maandelijks of af en toe verscheen, gestencild of op offset, dan weer gestencild of plots rijkelijk geillustreerd, op A4- of A3-formaat, met titels met een heel ander uitzicht of zelfs een tijdschrift volgens een volledig nieuwe formule. De lezers waren kennelijk niet altijd even opgezet met deze gedaanteverwisselingen.

Bij de berichtgeving stond het ideaal van de 'information brute' voorop. Dit hield in dat analyse en commentaar geweerd werden en alleen harde feiten aan bod kwamen. De keuze voor deze manier van berichtgeving vloeide niet uitsluitend voort uit de functie van apl als persagentschap, maar ook uit zijn kritiek op de zogenaamde objectiviteit van de traditionele pers. Als antwoord hierop wou apl de informatie 'telle quelle' presenteren aan de lezer, opdat die zich in alle vrijheid een eigen mening kon vormen. Het gaf de informatie in de vorm van korte berichten met aandacht voor wie, wat, waar, wanneer, waarom en hoe in een zo neutraal mogelijke bewoording, grammaticaal in uiterst simpele zinsconstructies. Door de jaren heen werd de stijl vlotter, synchroon met het steeds hogere tijdschriftgehalte. Het ideaal van information brute bleef behouden, wat niet belette dat daar de facto al eens een loopje mee werd genomen. Vooral de onzorgvuldigheid, onvolledigheid en onachtzaamheid waarmee met de informatie werd omgegaan, speelde apl parten, dit gaf er niet alleen een subjectief tintje aan, het kwam evenmin ten goede aan de geloofwaardigheid van de berichten. 
Het tijdschrift bestond aanvankelijk enkel uit tekst, vanaf het nummer 358 was het geïllustreerd. Parallel met de geleidelijke overgang naar offsetdruk, werden in een eerste fase enkel de vier omslagpagina's in offset gedrukt en geïllustreerd. Pas toen het tijdschrift volledig in offset verscheen, doken er overal prenten en foto's in op, en dit tot en met het laatste nummer. Dat het tijdschrift vanaf een bepaalde periode niet langer alleen verbale maar ook visuele informatie omvatte, was niet zonder consequenties voor de globale betekenis ervan. Want, hoewel de visuele informatie grotendeels in dezelfde lijn lag van de tekstuele, leidde ze tegelijkertijd een eigen leven. De foto's en prenten belichtten dezelfde thema's als in de artikels, maar de toon van de afbeeldingen was verschillend. Expliciet, dan wel impliciet droeg het beeldmateriaal duidelijk een boodschap uit die verweven was met de centrale thema's van de sociale strijd, het subjectieve gehalte dat apl zoveel mogelijk wou vermijden in de verbale informatie, was in de visuele kennelijk geen probleem. Op die manier werd dan toch commentaar geleverd zonder dat getornd werd aan het ideaal van de information brute wat de artikels zelf betrof. Het illustreren van het tijdschrift was met andere woorden een vorm van betekenisgeving op zich.

\section{Eindjaren van apl}

Apl-b kende een lange eindfase, grofweg van 1983 tot en met 1993 of zowat de helft van zijn hele levensduur. In deze periode sloeg het radicaal een andere weg in door het aantal publicaties te verminderen en van het documentatiecentrum zijn hoofdactiviteit te maken. Deze omslag hield verband met de wisselende ploeg medewerkers en ook met de veranderende maatschappij. De tijdgeest had het militante doen afnemen waardoor steeds minder mensen zich aangetrokken voelden tot apl. Op het gebied van pers en communicatie was een nieuwe fase aangebroken, een ware informatiseringsgolf kwam eraan. Bovendien bleek nu ook de traditionele pers steeds meer geïnteresseerd in het soort informatie die apl lange tijd zo fel bevochten had. ${ }^{(18)}$

In vergelijking met soortgelijke initiatieven is de levensduur van apl zeer lang te noemen, al is enige nuance vereist. Apl's bloeiperiode of 'époque centrale' betrof pakweg een zevental jaar, van eind jaren 1970 tot en met begin jaren 1980. De eerste jaren waren eerder een aanloopfase, de laatste jaren een zoeken naar overleven door een generatie die stilaan afgelost werd. In de woorden van Monique Quintart samengevat: "L'apl avait joué son rôle [...]. C'était un mouvement. Il fallait que ça s'arrête. Il était temps pour autre chose.” ${ }^{19)}$

\section{De vele gezichten van apl}

Apl is altijd trouw gebleven aan zijn doelstellingen: eigen beheer, onafhankelijkheid, information brute, lezers als medewerkers, strijd op het vlak van informatie, 'donner la parole 
au peuple', pluriformiteit, maatschappelijke verandering, vrije communicatieruimte, 'pouvoir informatif' bleven behouden tot op het laatste ogenblik. Wat wel veranderde was de concrete vorm waarin apl deze doelstellingen realiseerde.

Het is opmerkelijk dat apl constant van haast onopvallende tot zeer ingrijpende, wispelturige en radicale gedaanteverwisselingen heeft ondergaan. In eerste instantie vloeiden deze voort uit de vrees dat een aantal doelstellingen eeuwig dode letter zouden blijven zodat het leek of apl zichzelf voortdurend in vraag stelde en op zoek was naar de perfecte formule om deze te concretiseren. Een masterplan was hiervoor niet voorhanden; er werd geopteerd voor de formule van trial-and-error. Voorbeelden van reflectie en gedaanteveranderingen zijn legio. $\mathrm{Nu}$ eens richtte apl zich tot de lezers met de vraag een enquête in te vullen of in een brief kritiek te leveren op de aard, hoeveelheid en soort illustraties in zijn tijdschrift, dan weer hield het 'reflectieweekendjes' of verscheen het tijdschrift een poosje niet zodat de medewerkers in alle rust konden nadenken over de journalistieke lijn, het gezicht van het tijdschrift, de vorm van actievoeren en de praktische werking. Het meest tastbare voorbeeld van apl's gedaanteverwisselingen zijn de - meestal onaangekondigde en ongemotiveerde - aanpassingen van het tijdschrift qua titel, kleur, lettertype, paginering, rubrieken, periodiciteit ...

Naast de zelfbevraging vanuit de vaststelling dat er een gapende kloof bestond tussen (sommige) doelstellingen en realiteit, speelden nog een tweetal andere factoren mee in de gedaanteveranderingen van apl. Enerzijds bestond apl uit een steeds vernieuwde ploeg van medewerkers met nieuwe ideeën, wat zijn weerslag had op de werking, anderzijds was er de veranderende samenleving en aangezien apl niet in een vacuüm functioneerde, had ook dit zijn impact.

Apl kan bijgevolg omschreven worden als iets 'fluctuerends' en ook dat is een kenmerk van de alternatieve pers uit die tijd. Of zoals apl het zelf schalks verwoordde: "Désormais, vous direz: 'apl? Mais bien sûr, je connais l'apl.' Non. D'ailleurs, je préfere ne pas conclure car ici, la conclusion est toujours reportée [...].” (20)

\section{Erkenning of miskenning? (21)}

De traditionele pers heeft apl nooit erkend als persagentschap of volwaardige bron van informatie. Een gevoel van misprijzen en minachting was overheersend. ${ }^{(22)}$ Pourquoi Pas? schilderde de acties van apl bijvoorbeeld af als een 'intoxication gauchiste', La Libre Belgique noemde apl een 'Agence de Presse d'extrême gauche Libération' en Belga liet apl botweg weten dat het nu maar eens gedaan moest zijn om via hem berichten te willen verspreiden: Apl was toch zelf een persagentschap! La Dernière Heure ging zelfs zo fel tekeer dat apl een rechtszaak aanspande toen die krant weigerde een recht op antwoord te respecteren. De traditionele pers zag apl als een rood nest, een militante bende revolutionaire manipulatoren, een kliek propagandisten die waardeloze informatie verspreidden. 

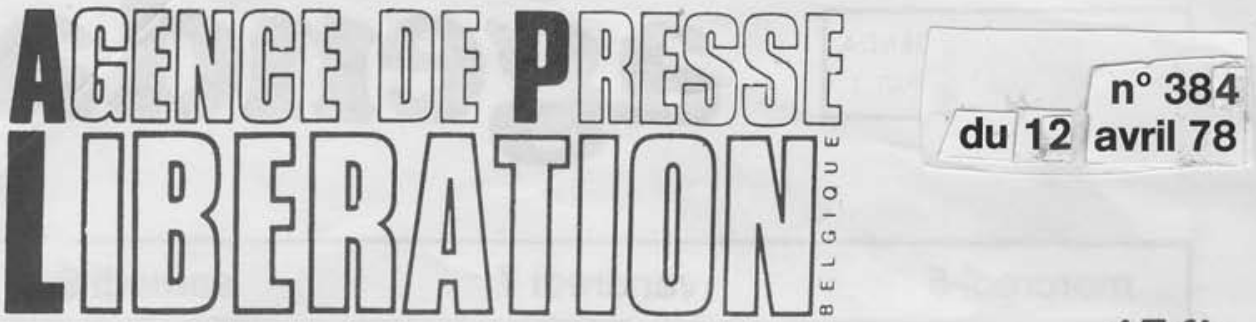

35 RUE DE L'INQUISITION

1040 BRUXELLES

BANQUE No 001.0536870.51

$15 \mathrm{fb}$
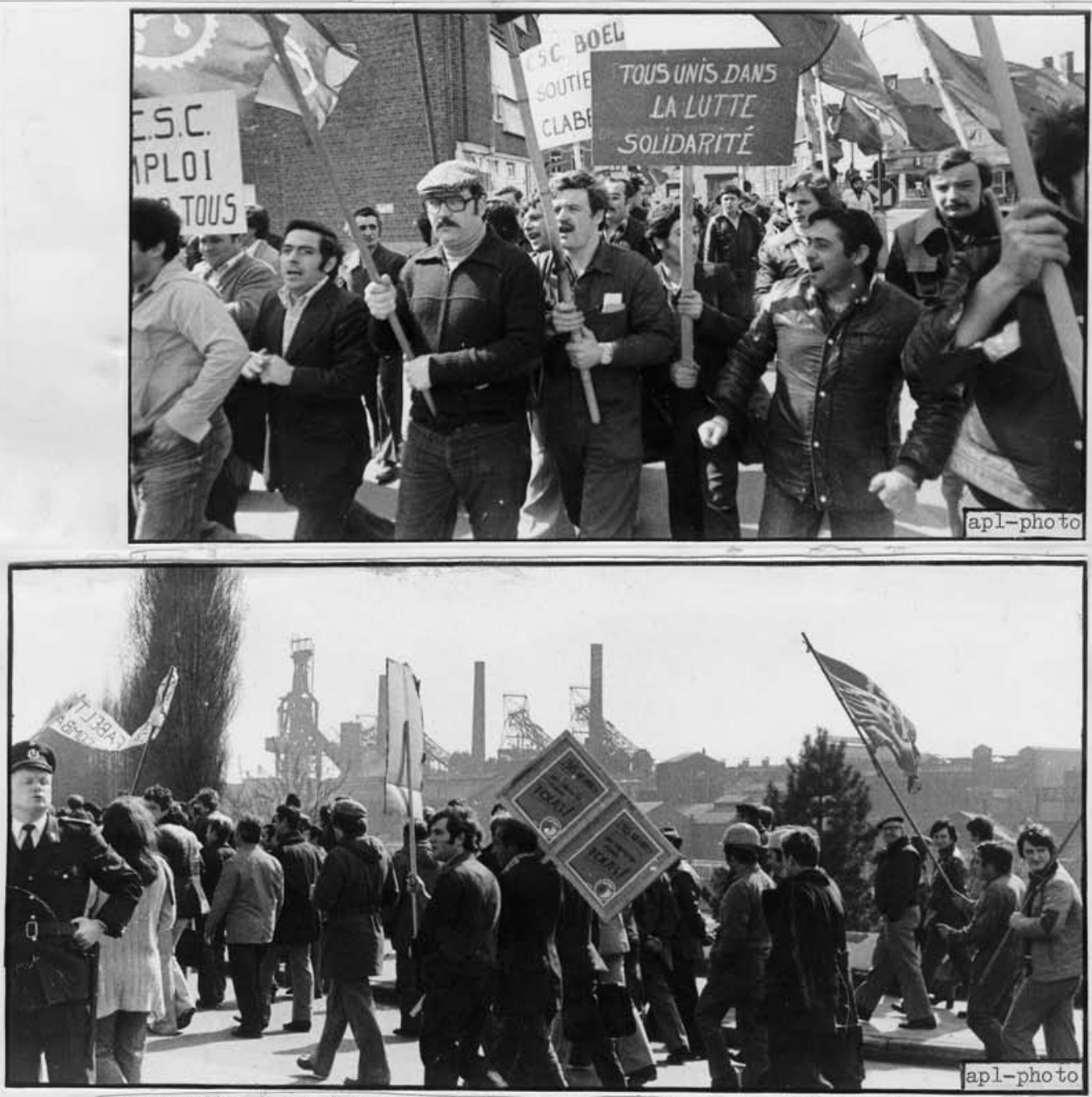

CLABECQ ( 7.4.78) Manifestation des travailleurs des Forges de

Clabecq et de Bö̈l pour la défense de l'emploi.

l'arme de vos informations

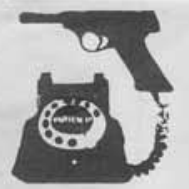


Of de traditionele pers desondanks gebruik maakte van de informatie die apl verspreidde - het stond immers vrije reproductie ervan toe - is moeilijk te achterhalen. Zeker is dat 'la grande presse' in de beginperiode van apl een artikel al eens durfde aanvangen met "L'Agence de Presse Libération annonce que ...". De verwijzing naar apl verviel echter al snel, vermoedelijk was de overname van apl's informatie verwaarloosbaar klein. Dat de traditionele pers apl niet wou erkennen, heeft niet verhinderd dat een aantal individuele journalisten, weliswaar op hun thuisadres, geabonneerd waren op het tijdschrift en zich beriepen op apl's informatie. (23) Vooral een aantal journalisten van RTB-radio maakte af en toe gebruik van het tijdschrift. De linkse-alternatieve pers daarentegen zoals Pour, Notre Temps, Hebdo, La Gauche, La Revue Nouvelle en een handvol vrije radio's gebruikten apl enthousiast als bron; andere, zoals de marxistisch-leninistische pers, vonden apl dan weer te gematigd, niet revolutionair genoeg en te democratisch.

\section{Conclusie}

Apl-b mag met recht en reden een schoolvoorbeeld genoemd worden van de alternatieve pers die in de nasleep van mei '68 ook in België ingang vond. Tegenover de negatieve vaststelling van een zogenaamde lacune in de traditionele pers op het vlak van informatie, wou apl een positief alternatief aanreiken. Centraal stond het idee van informatie over, van en door het volk.

Wat het informatieproces betreft, verzette apl hemel en aarde opdat de lezers ook schrijvers zouden worden en de informatieverspreiding van a tot $\mathrm{z}$ volledig zelf in handen zouden nemen. Een echt onderscheid tussen lezers en vaste kern van apl was er niet; communicatie gebeurde op een horizontale manier. In dezelfde lijn stonden op organisatorisch vlak de principes collectiviteit, zelfbestuur en vrijwilligerswerk centraal. Professionalisme en specialisatie waren uit den boze, hiërarchie werd koste wat het kost vermeden.

Wat de informatie zelf betreft, kenmerkte apl-b zich door alternatieve selectiecriteria, het liet een wereld zien van onderuit, van het gewone volk, van mensen die een andere maatschappij voorstonden. Het gehanteerde perspectief was pluralistisch. Apl zelf was vrij gematigd, maar bracht in zijn tijdschrift meer radicale of net meer gematigde boodschappen.

Toch zat apl op de een of andere manier in een getto. Vraag is of het er wel uit wou, het was er immers in geslaagd ruimte te creëren voor alternatieve discussie en debat binnen een complexe structuur van alternatieve economische praktijken, alternatieve organisatie en sociale actie.

Cover van het apl-tijdschrift, 1978 
Men kan stellen dat apl-b, eerder dan mislukt te zijn in zijn opzet, erin geslaagd is de alternatieve doelstellingen die het voor ogen hield effectief in de praktijk om te zetten of althans deels. Het kon in ieder geval een maatschappelijke functie vervullen, wat wellicht zijn primaire doelstelling was.

(1) De belangrijkste hedendaagse werken zijn: A. GRYSPEERDT, Les nouveaux courants de la presse francophone en Belgique après mai 1968: la contra-information régionale, locale et sectorielle. In: CH. CRISP, (1979)845-846, p. 141; Canards en chaîne, Répertoire unique et incomplet d'une presse 'alternative' plus ou moins sporadique, Ittre: Mediacom-Presse, 1980; J.-C. DIETSCH, Aujourd'hui une «autre» presse? In: Études, (1972), p. 385; M. PHILLIPART, Sauvages, ces canards? La petite presse en Belgique francophone. In: La Revue Nouvelle, LXXIV, (1981)7-8, p. 55- 68; C. ATTON, Alternative Media, London: Sage Publications, 2002, 172 p.

(2) Voorbeelden zijn de licentiaatsverhandelingen van Pascal Delaunois, jarenlang medewerker van apl-b en gedurende een bepaalde periode ook eindredacteur van het apl-tijdschrift: P. DELAUNOIS, L'Agence de Presse Libération-Belgique, ULB, Mémoire de Licence, 1974, en van Christian Vanderwinnen, permantent medewerker van het tijdschrift Pour: C. VANDERWINNEN, Structures et projet d'un hebdomadaire belge élaboré par un groupe de militants marxistes. 'Pour, un journal au service des luttes', ULB, Mémoire de Licence, 1975.

(3) T. LUYCKX, Evolutie van de communicatiemedia, Brussel: Elsevier, 1987, 576 p.; E. DE BENS, De pers in België. Het verhaal van de Belgische dagbladpers, gisteren, vandaag en morgen, Tielt: Lannoo, 1997, 480 p.; E. WITTE, Media en politiek. Een inleiding tot de literatuur, Brussel: VUBPRESS, 1991, 243 p.; J.M. VAN BOL, De sociale communicatiemedia in België. In: Teksten en documenten, verzameling 'Ideeën en studies', Brussel: Ministerie van Binnenlandse Zaken, Buitenlandse Handel en Ontwikkelingssamenwerking, 1975, 118 p.; E. LENTZEN, Petit panorama de la presse belge. In: La Revue Nouvelle, LXVI, (1997)9, p. 161-166.

(4) E. DE BENS, De pers in België [...], p. 66-67.

(5) Met de term 'Stille Revolutie' duidt Ronald Inglehardt de contestatiebeweging aan die eind jaren 1960 de kop opstak, gaande van het verzet van de nieuwe sociale bewegingen, met de studentenbeweging voorop, tot het protest van de arbeidersklasse.
(6) KBR, BD 30 259, nr. 300; ULB, MEM. T05321 M.; Amsab-ISG, S/2004/036, Interview met Michel Veys, Schaarbeek, 13.11.2003; Interview met Pascal Delaunois en Monique Quintart, Ukkel, 06.12.2003.

(7) Jean-Paule Sartre speelde vooral een symbolische rol in apl-France. Hij was eerder al opgetreden als directeur van La cause du Peuple en van het eenmalig gefuseerde J'Accuse-La cause du Peuple, alsook van de publicaties Tout! en Révolution. Sartre stond op die manier symbool voor zowat de hele linkse alternatieve pers in Frankrijk. Zie: Histoire générale de la presse française de 1958 à nos jours, Paris: Presses universitaires de France, s.d., p. 410.

(8) De Belgische pers krijgt regelmatig alternatieve informatie. Ook in Brussel opereert een Agence de Presse Libération dat telkens de andere klok wil laten luiden. In: De Nieuwe, (1973)486, p. 6-7; Connaissez-vous l'apl? In: L’Oreille (supplément), (1977)26; On en parlera demain. L'Apl, une agence au service des luttes du peuple. In: La Cause du Peuple, (1973)2, p. 11; Amsab-ISG, doos 194, aanvraagformulieren apl CST en TCT; Amsab-ISG, doos 194, Petit mode d'emploi de l'information.

(9) KBR, BD 30 259, nr. 275.

(10) Canards en chaîne [...], p. 22;

A. GRYSPEERDT, Les nouveaux courants [...], p. 14; Amsab-ISG, doos 228, briefwisseling apl 1976; Amsab-ISG, S/2004/036, Interview met Michel Veys, Schaarbeek, 13.11.2003; Interview met Pascal Delaunois en Monique Quintart, Ukkel, 06.12.2003.

(11) In het tijdschriftnummer 379 meldde apl 400 betalende abonnementen te hebben; in het nummer 400 werd feestelijk aangekondigd dat de kaap van 500 overschreden was; in het nummer 422 dat het aantal alweer gezakt was tot 450 .

(12) Amsab-ISG, doos 232, evaluatierapporten apl TCT, 1981-1982.

(13) Om te achterhalen welke onderwerpen precies belicht werden in het apl-tijdschrift en of hierin een evolutie merkbaar was, heb ik steekproefsgewijs de kwantitatieve methode toegepast. Zie 
hiervoor: A. WATERINCKX, Parce que l'information, c'est vous! Alternatieve pers in Franstalig België na mei '68, casus Agence de Presse Libération - Belgique, UGent, licentiaatsverhandeling, 2004, p. 136-150.

(14) KBR, BD 30259 , nr. 379.

(15) KBR, BD 30 259, nr. 235; Canards en chaîne [...], p. 22.

(16) Btk of bijzonder tijdelijk kader werd in 1978 uitgedacht door minister Spitaels en kaderde binnen de overheidsmaatregelen om de werkloosheid terug te dringen. Btk'ers konden tijdelijk tewerkgesteld worden in het kader van een project, hun vergoeding kwam voor de rekening van de overheid; btk'er behielden het statuut van werkloze.

(17) Om te achterhalen hoe de informatie in woord en beeld werd weergegeven, heb ik het apl-tijdschrift stelselmatig doorgenomen. (KBR, BD 30 259). Zie hiervoor: A. WATERINCKX, Parce que l'information [...] p. p. 150-169.

(18) Deze trend zet zich nog steeds voort. Getuige de oproep van verschillende media om nieuws via sms of e-mail door te sturen.

(19) Amsab-ISG, S/2004/036, Interview met Pascal Delaunois en Monique Quintart, Ukkel, 06.12.2003

(20) Canards en chaîne [...], p. 22.

(21) ULB, MEM. T05321 M; Amsab-ISG, S/2004/036, Interview met Michel Veys, Schaarbeek, 13.11.2003, Interview met Pascal Delaunois en Monique Quintart, Ukkel, 06.12. 2003.

(22) Zie respectievelijk Amsab-ISG, doos 29, krantenartikel Pourqoui Pas?, Lintoxication gauchiste (14/07/77); doos 129, La Libre Belgique, Le commissaire fou (16/01/78); doos 228, brief van Belga (19/12/77), doos 129, Affaire Brébart, apl contre la Dernière Heure (1977- 78).

(23) VAN ROMPAEY, L'amant et l'aval: Belga et l'AMP. In: La Revue Nouvelle, LXVI(1979), p. 9; De Belgische pers krijgt regelmatig alternatieve informatie. Ook in Brussel opereert een Agence de Presse Libération dat telkens de andere klok wil laten luiden. In: De Nieuwe, (1973)486, p. 6. 